\title{
The Use of Digital Channels as a Marketing Tool in Ceramic SMEs
}

\author{
Poppy Ruliana ${ }^{1}$, Irwansyah ${ }^{2}$, Susi Andrini ${ }^{3}$, Kurnia $^{4}$ \\ ${ }^{1}$ STIKOM InterStudi, Jakarta, Indonesia \\ ${ }^{2}$ Communication Studies. FISIP. University of Indonesia, Depok, 166424 \\ ${ }^{3}$ STIKOM InterStudi, Jakarta, Indonesia \\ ${ }^{4}$ STIKOM InterStudi, Jakarta, Indonesia \\ Corresponding Author's Email: Poppyruliana30@gmail.com
}

\begin{abstract}
This study aims to clarify the digital channels used by ceramic SMEs in the Plered Ceramics Industry Center, Purwakarta Regency. The concepts used are digital media, social media, one-way communication channels and two-way communication channels, SMEs. The approach used in this research is quantitative and the method used is descriptive which is a method that presents a further observation stage. After having a set of classification schemes, such as investigators, then measuring the magnitude or distribution of traits among members of certain groups, in this case the role of statistical techniques arises, such as frequency distribution. While the samples in this study were 22 ceramic, documentation and internet SMEs entrepreneurs. The analysis technique used in this study was applied quantitatively and qualitatively. Quantitative research is intended to process field data into tabular form then distribute it into frequency table form using the formula $\mathrm{n}=\mathrm{f} / 100 \%$ and be interpreted further qualitatively. The results show that some SME ceramics entrepreneurs have not yet fully used digital and social channels, they tend to use direct and indirect two-way communication channels to market ceramic products.
\end{abstract}

Keywords: digital media, channels, social media, SMEs

\section{INTRODUCTION}

The existence of Small and Medium Enterprises (SMEs) is very strong because it is spread throughout Indonesia and controls $99 \%$ of business activities in Indonesia and $98 \%$ of microbusinesses and has advantages in that are specific focus ability factors, national flexibility factors, low cost factors, and the speed factor of innovation even though during the global crisis that had hit Indonesia, the contribution of SMEs in the economy was still standing tall. Therefore, the role of SME is quite strategic, especially the contribution to gross domestic product. This can be seen from the economic development in Indonesia recently increased by 0.05 percent. One of the supporters of economic development can be seen from the development of small business businesses, both in traditional and modern sectors through SMEs) (in the incubator website, 2018). Then according to data from the Ministry of Cooperatives and Small and Medium Enterprises, it is estimated that 3.79 
million SMEs (have used online media. This number is around 8 percent of the total SMEs in Indonesia, which is 59.2 million (in the Kominfo.go.id website, 2017)

Another problem arises, possibly due to the relatively low level of formal education among ceramic SMEs. Previous research conducted by Ruliana (2008) showed that formal education among low-ceramics SMEs was generally junior high schools, which amounted to 55\%, and $10 \%$ were elementary schools, senior high schools (30\%) and the rest graduated from college. This is most likely a lack of understanding of the strategic role that digital media can play in relation to new approaches to marketing, interacting with consumers, and even the development of products and services allegedly as a reason for the low adoption of digital media by SMEs in Indonesia. A survey conducted by Indarti (2007) of SMEs in Yogyakarta, the reason for SMEs not using a computer is because they do not feel the need $(82.2 \%)$, limited financial support $(41.1 \%)$, and because they do not have the expertise to use ( $4.1 \%$ ), this also happened among the Ceramic SMEs in the Plered Ceramics Industry Center, Purwakarta Regency. The results of research conducted by Ruliana et al (2018) show that computer use is relatively low because it is still weak in planning, strategic thinking and long-term views. This tendency has made ceramic SMEs difficult to overcome market competition in Indonesia due to the lack of information they received and the ceramic SMEs have not positioned themselves as quality entrepreneurs, and creativity to face competition has not been optimal.

However, even though the Government has launched the use of online media, the problem faced by MSMEs is formal education. Previous research conducted by Ruliana (2009) showed that formal education among ceramic SMEs was low, generally junior high school, $55 \%$, and $10 \%$ elementary school, senior high school $(30 \%)$ and the rest graduated from college. This has an impact on the lack of understanding of the strategic role that digital media can play in relation to new approaches in marketing, interacting with consumers, and even the development of products and services that are considered as the reasons for the low adoption of digital media. So some SMEs consider it less important and economic factors as one of the reasons. Similarly, a study conducted by Indarti (2007) on SMEs in Yogyakarta, showed why SMEs do not use computers because they do not feel the need $(82.2 \%)$, limited financial support $(41.1 \%)$, and because they do not have expertise to use $(4.1 \%)$, this also happened to Ceramic SMEs located in the Plered Ceramics Industry Center, Purwakarta Regency. The results of research conducted by Ruliana et all (2018) show that computer use is relatively low because it is still weak in planning, strategic thinking and long-term views. This tendency makes it difficult for ceramic SMEs to overcome market competition in Indonesia because of the lack of information they receive and ceramic SMEs have not positioned themselves as quality entrepreneurs, and creativity to face competition is not optimal. In connection with the description above, according to Kaplan and Haenleinm (2010) states that digitalization, and especially social media, has claimed to change consumer behavior with important consequences for companies, products, and brands (Muntinga et al 2011). While the results of research conducted by Forrester Research (2008) and Nielsen (2012) show that 
consumers spend a lot of time online and use social media. They use online services to search, store and send e-mails, access Facebook, Twitter and applications with various connected devices such as smartphones, tablets, and laptops, and it changes the way the internet is used. However, it seems that many SMEs have not used online media. In the case of the use of the Internet media can benefit SMEs by reducing costs (Chong and Pervan, 2007). The latest developments in digitalization, namely the social aspects of the web has confirmed the positive relationship between utilization and results. In a study conducted by Barnes et al. (2012) found that out of 12 SMEs in the UK, the social aspects of the web can increase efficiency and external communication. The results of research conducted by Cesaroni and Consoli (2015) found that the use of digital media is to expand SME assistance and support to increase public awareness, open new methods in business and sharing, collaborate and create innovative concepts to improve the best performance. Swarna (2015) shows that social media platforms are free communication services

Based on the description above, the purpose of this study is to explain to explain the digital communication channels and what factors support and inhibit the challenges faced by Ceramic SMEs in the Plered Ceramic Industry Center, Purwakarta Regency

\section{LITERATURE REVIEW}

In this study the concept used refers to research conducted by Heini, Taiminen \& Heikki, (2015) entitled The usage of digital marketing channels in SMEs and research conducted by Caiyong Zhuang, et al. (2017) entitled The Analysis of Digital Marketing among SMEs in Chaozhou City that distinguishes it from the research I do with research lies in the use of research methods and objects.

\section{Digital Media Channels As SME Marketing Tools}

Digital Media Channels According to Jarvinen et al. (2012) and Liu et al. (2011) state that digital marketing is a new approach to marketing, not just traditional marketing driven by digital elements. It has its own characteristics, and dynamics, which must be understood to be able to choose effective marketing tactics and strategies

According to Brent and Stewart (in Ruliana, 2016) Channels are tools used by communicators to disseminate or distribute messages with the aim of getting responses or reciprocity. This communication channel consists of interpersonal channels and Bulk channels. Interpersonal channels can be direct, such as face-toface communication and indirect channels, such as telephone, SMS, and WhatsApp. While mass channels, namely mass media, in the form of print media, such as newspapers, magazines, brochures, and electronics such as television and radio and internet networks, such as websites, e-mails, Facebook, Instagram, Twitter, and so on. Each media has different influences, depending on the communication goals to be achieved. 
Digital channels can be carried out through one-way communication channels and two-way communication channels. One way to classify channels is to present them based on the perspective of which party controls the communication (the company or target an audience) and whether the communication is one-way or twoway (Heini, Taimine \& Heikki, 2015, Caiyong Zhuang, et al. 2017).

Stockdale, Ahmed, and Scheepers (2012) succeeded in identifying business value from the use of social media for MSMEs, such as: creating a continuous marketing channel; increase short-term income land long-term sales; advertising costs decreased by $70 \%$; as a whole can reduce marketing costs; can create competitive advantage; facilitate promotion across social media platforms; brand popularity can increase and products; introduction of the organization or company to the community.

\section{One-way Communication Channels}

Technology has provided convenience in the communication process. One of them is providing services in the form of internet networks. Internet network is a media liaison between computer devices or smartphones with cyberspace. The existence of this internet network makes it easy for humans to communicate through cyberspace without the constraints of time and space. Communication that uses this technology is called digital communication. The website is a digital and internet based information page. Websites or often known as the web are used by various formal or informal companies or institutions. Websites are usually paid and function as corporate information media. The company's email website can be described as a home brand in the online environment of Christodoulides, (in Heini, Taimine \& Heikki, 2015, Caiyong Zhuang et al, 2017). Within, the web can also be used to provide information in the form of news portals such as online media that are increasingly developing to present the latest news to the wider community. This website is an example of a digital communication channel that is able to provide ease of communication in the community.

\section{Two-way Communication Channels}

Social media has changed the marketer-customer relationship; so far the power has shifted from marketers to customers (Hennig-Thurau et al. 2010). The important nature of social media requires ceramic SME entrepreneurs to take the form of two-way communication to "talk" to customers because of the e-mail is often used as a one-way channel for sending bulletins or advertisements even though e-mail is a two-way communication channel. (Simmons, 2007). Naturally, companies lack control with their brand on social media channels. Hearings do not expect commercial messages, but real information about companies and brands when companies use social media to reach them (Fournier \& Avery, 2011). Blogging is also a form of two-way social communication channels where companies maintain a fairly high level of control because the blog content is usually edited and comments are monitored by their owners, said marketing and PR are good tool (Ahuja \& Medury, in Heini, Taimine \& Heikki, 2015, Caiyong Zhuang, et al. 2017). 


\section{SMEs (Small and Medium Enterprises)}

Based on Presidential Decree no. 99 of 1998 the definition of Small Business is: "Small-scale community economic activity with a business sector which is largely a small business activity and needs to be protected to prevent unfair business competition." Small and Medium Enterprises, abbreviated as SMEs is a term that refers to the type of small business that has a maximum net worth of RP. 200,000,000 (two hundred million rupiah) excluding land and buildings where the business is located and independent business. Then, according to the Central Statistics Agency, SMEs are divided into several sections, namely: (i) household businesses have: 1-5 workers, (ii) small and medium-sized businesses: 6-19 workers, (iii) medium-sized businesses: 20 -29 workers, (iv) Big business: more than 100 workers. Furthermore, SMEs in Indonesia can be divided into four criteria, namely: Livelihood Activities: Small and Medium Enterprises are used to make a living and are better known as the informal sector. Example: street vendors Micro Business: Small and Medium Enterprises that are carried out by becoming craftsmen but do not yet have an entrepreneur. Small Dynamic Enterprises: Small and Medium Enterprises have an entrepreneurial spirit and accept jobs based on sub-contracts or exports. Moving Enterprise: Small and medium businesses that already have an entrepreneurial spirit and can turn into big businesses. This study focuses on small household businesses that have one to five workers and mediumsized workers with five. (in the pahlevi webpage, 2018)

\section{METHODOLOGY}

The approach used in this research is quantitative and the method used is descriptive which is a method that presents a further observation stage. After having a set of classification schemes, such as investigators, then measuring the magnitude or distribution of traits among members of certain groups, in this case the role of statistical techniques arises, such as frequency distribution and distribution (Mayer and Greenwood, in Ulber, 2009). The population in this study were all SMEs ceramic entrepreneurs, totaling 221 people. For the sample size, researchers took $10 \%$ of the population so that 22 SMEs ceramic entrepreneurs were made respondents. Data is collected through field observations to get information and data. Interviews were conducted with the Head of Ceramics SMEs Head of Ceramics Research and Development Unit at the Center for Ceramics Industry. the distribution of semi-structured questionnaires was conducted for SMEs ceramics entrepreneurs who were respondents, a study of documentation to obtain secondary data and an internet search to explore various information relevant to this research. Furthermore, data analysis is done through quantitative analysis and qualitative analysis. Quantitatively intended to process data obtained from the field and then distribute it into one table using the frequency distribution formula which is $\mathrm{n}=\mathrm{f}$ / $100 \%$. While qualitatively the data obtained is then interpreted in depth. Therefore this research combines quantitative and qualitative, 


\section{RESULTS AND DISCUSSION}

The following will explain the results of research and discussion conducted at the Plered Ceramic Industry Center, Purwakarta Regency, which begins with the profile of respondents, then the use of digital channels as a marketing communication tool and what obstacles are faced by ceramic SMEs entrepreneurs who are respondents in utilizing digital channels,

\section{Profile of Respondents}

Age affects respondents or SMEs entrepreneurs in increasing work productivity and age can be used as an indication of the experience and skills possessed by ceramic SMEs entrepreneurs at the Plered Ceramic Industry Center, Purwakarta Regency in running their business, and if seen in table 1 below, factors the age owned by respondents or ceramic SMEs entrepreneurs are generally included in the productive category so that respondents can provide ceramic design ideas or innovations that have different ceramic product differentiation from other ceramic entrepreneurs, both in the country and abroad so that they are able to compete

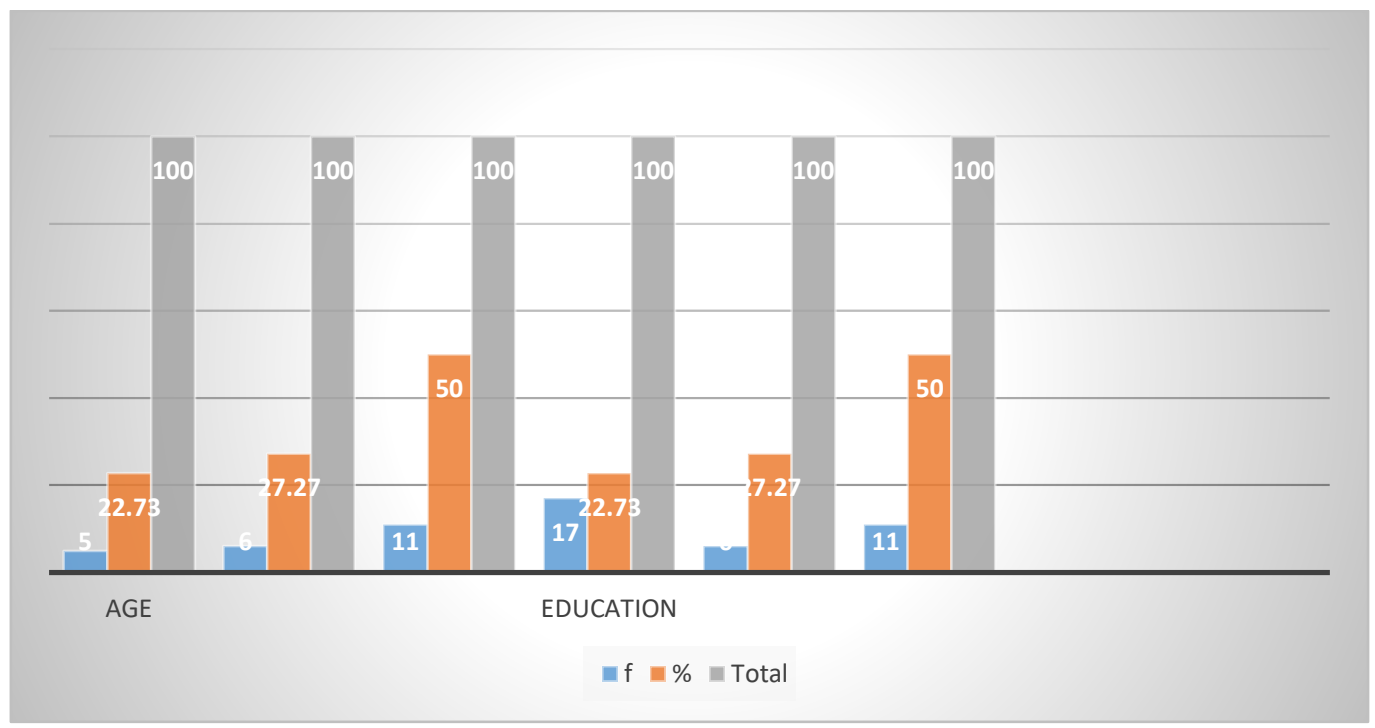

Table 1. Age And Educational Respondent (Source: Research Results, 2019)

In addition to the age factor, the education level of ceramic SMEs entrepreneurs greatly influences the understanding of messages about ceramic product innovations delivered, the education level of ceramic SMEs is mostly high school graduates as shown in the table above. However, even though their level of education is relatively low, they have experience other than that ceramics production is the main livelihood so they can increase production and develop the ceramics business as they attend informal education, such as education and training in ceramic design technology innovation skills with various types of ceramics, such 
as jars, flower vases and also take part in training in the use of social media, such as making the web, ordering content to the ceramic products market organized by the Regional Technical Implementation Unit for Ceramics Research and Development. The Ministry of Industry and Trade and SMEs of Purwakarta Regency, located at the Plered Ceramics Industry Center, Purwakarta Regency. The four potentials or advantages, according to Bambang Megawahyu (interview, 30 April 2019) are used as the basis in developing an increasingly competitive ceramic handicraft business, various opportunities can be achieved in increasing sales value mainly due to the ability of ceramic craftsmen who are relatively skilled and already trained, also in terms of product design development varies. Therefore, the government through the Ceramic Regional Research and Development Technical Implementation Unit under the Department of Cooperatives, SMEs, Industry and Trade Purwakarta Regency helps ceramic SMEs to take part in national exhibitions or in workshop activities organized by UPTD Ceramic R\&D or any private company. The impact of these activities, the number of orders both from the domestic market (domestic) and foreign markets (international) so that the ceramic craftsmen need to make plans for a broader market penetration.

Based on the age and education level of the respondent, the respondent's experience factor and the number of employees owned are important factors that can influence the skills of making ceramics design and the improvement of ceramics production, as shown in table 2 below.

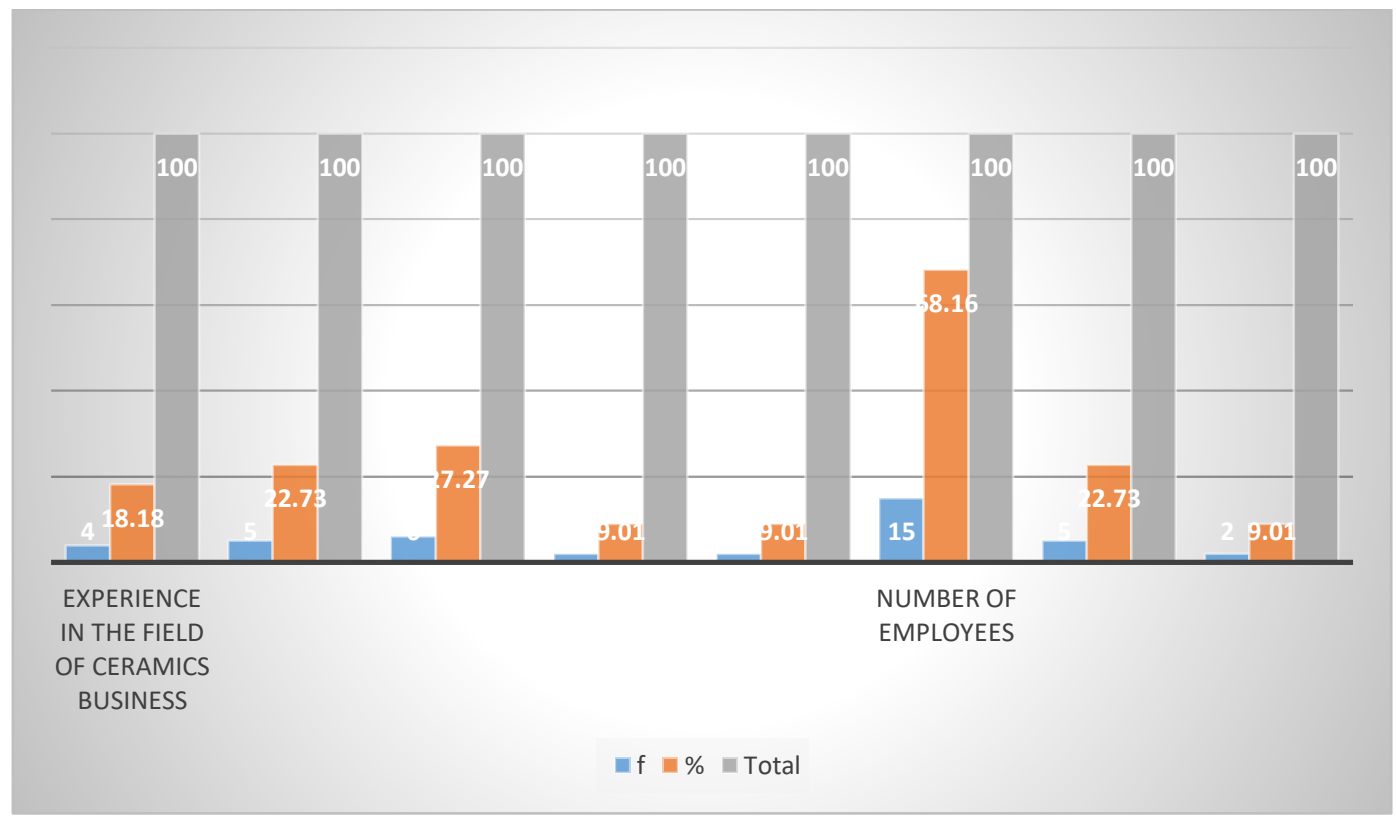

Table 2. Experience In Ceramics Business And Number Of Employees. (Source: Research Results, 2019) 
The highest number of employees owned by SME ceramics entrepreneurs is 1-5 employees by $68 \%$, then other SME ceramics entrepreneurs have 6-10 employees with a total of $22.73 \%$ employees, the rest have $11-19$ employees $-9.1 \%$ employees. Most of them are experienced ceramics business owners and have employees who help process, manage, and process ceramic raw materials into ceramics and designs by following market demands and increasing ceramics production to be ready for sale. So ceramic SMEs in the Plered Ceramics Industry Center, Purwakarta Regency are included in the category of Small Business, and small and mediumsized businesses according to the Central Statistics Agency's explanation that SMEs can be divided into several sections, namely: (i) household businesses have: 1-5 workers, (ii) small and medium enterprises: 6-19 workers. These employees have expertise in processing ceramic raw materials into ceramics, designing innovative products without leaving the characteristics possessed by ceramic SME entrepreneurs, and most importantly following market tastes.

\section{Ceramic Media SMEs Digital Channel}

According to research findings, more than half (85\%) of respondents said they used digital marketing that was poor or very bad and only $15 \%$ used digital channels as a tool to market ceramic products among Ceramic SMEs. The low use of digital channels is caused by several factors. From the results of interviews conducted with SMEs obtained that information

they are difficult to determine investment because of the cost factor, especially to buy a laptop or computer that can be used to market products other than that to use the web they consider very expensive. It is better to use the cost to produce ceramics even though we are aware that digital media can be used as a channel for marketing ceramic products. Besides the cost factor, other factors are human resources and sufficient knowledge about digital channels

What was said by respondents, in this case SME ceramic entrepreneurs, in accordance with the findings of research Gilmore et al. (2007) shows that SMEs do not have adequate human, capital and knowledge resources in adopting digital channels. This reflects that the lack of human resources, time and expertise possessed by ceramic SME entrepreneurs is the biggest obstacle in developing the SMEs ceramic industry and it is important to be noticed by the Regional Government. However, some SMEs ceramic entrepreneurs utilize digital communication channels and feel the benefits well. This shows that SMEs entrepreneurs who have adopted planned digital channels and consider the importance of developing information and communication technology, which they can use to sell ceramic products through the Website, Facebook, WhatsApp, Instagram so that the public is interested even though a small percentage. 
Based on the research results, the most commonly used digital channels in marketing ceramic SMEs products are websites and social media, namely Facebook, which is used actively by several respondents $(15 \%)$ of respondents. From the results of interviews conducted on three ceramic SMEs obtained information that they have a website that is considered the most important digital communication channel for marketing and communicating with consumers or customers, the other digital channels that are most often used and rated as the most important are brochures, living order. In addition, more than half of the respondents $(85 \%)$ did not use digital channels. But using direct interpersonal communication channels, such as offering their products directly to consumers or customers. Then other findings in the field that they also use interpersonal communication channels indirectly via telephone, SMS and WhatsApp which according to them have a direct impact, and the results are many orders and consumers who come to the store In line with the findings of this study, the results obtained from the use of this digital communication channel, they can obtain product orders, both nationally and internationally as shown in the table below.

\begin{tabular}{|l|c|}
\hline Region / Country & $\begin{array}{c}\text { Percentage of } \\
\text { Absorption }\end{array}$ \\
\hline Bandung & 20 \\
\hline Jakarta & 25 \\
\hline Denpasar & 5 \\
\hline Yogyakarta & 5 \\
\hline Surabaya & 5 \\
\hline Lombok & 5 \\
\hline America & 2 \\
\hline Japan & 2 \\
\hline Taiwanese & 2 \\
\hline Korea & 3 \\
\hline Netherlands & 5 \\
\hline Saudi Arabia & 2 \\
\hline English & 1 \\
\hline Canada & 1 \\
\hline Singapore & 4 \\
\hline Austria & 3 \\
\hline
\end{tabular}

Table 3. Digital channels in marketing ceramic SMEs products based on country

Based on the research results, the most commonly used digital channels in marketing ceramic SMEs products are websites and social media, namely Facebook, which is used actively by several respondents (15\%) of respondents. From the results of interviews conducted on three ceramic SMEs obtained information that they have a website that is considered the most important digital communication channel for marketing and communicating with consumers or 
customers, the other digital channels that are most often used and rated as the most important are brochures, living order. In addition, more than half of the respondents $(85 \%)$ did not use digital channels. But using direct interpersonal communication channels, such as offering their products directly to consumers or customers. Then other findings in the field that they also use interpersonal communication channels indirectly via telephone, SMS and WhatsApp which according to them have a direct impact, and the results are many orders and consumers who come to the store In line with the findings of this study, the results obtained from the use of this digital communication channel, they can obtain product orders, both nationally and internationally as shown in the table below.

The types of products marketed include jars, household appliances, piggy banks, flower vases, with attractive colors as shown in the picture below:
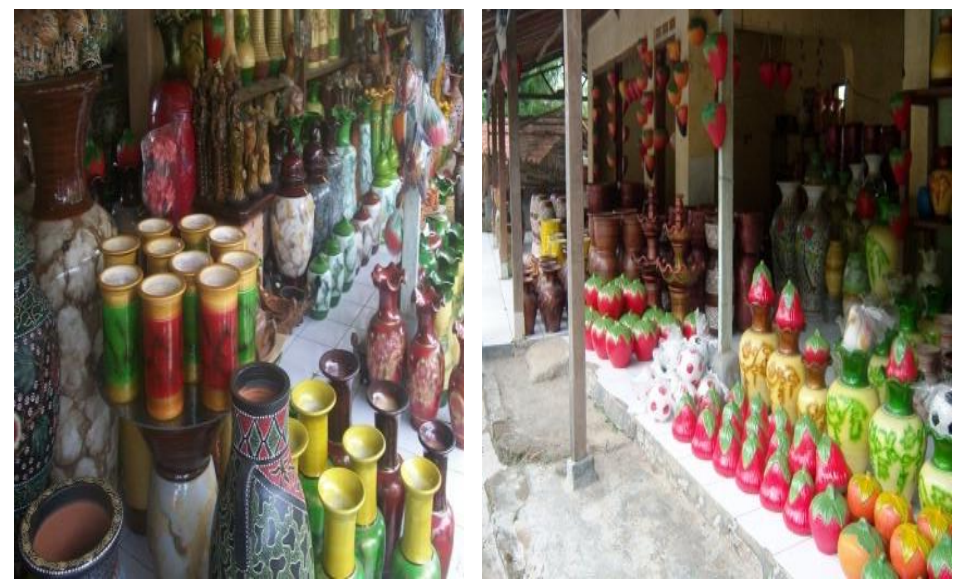

Figure 1: Various Types of Plered Ceramics Products Source: in the Ceramic Plered webpage

The color of ceramics mentioned above is preferred by the domestic market share and many orders are accepted by ceramic SMEs. However according to the Head of UPTD Ceramic Research and Development states that:

types of ceramic orders for export quality are different, they order a lot of types of products whose color is natural, such as the color of the ground, especially for the Plered Market. Because the characteristic of ceramic products is because Purwakarta is indeed known as one of the centers of handicraft made from clay, such as in the Center of Ceramic Industry in the District of Plered 

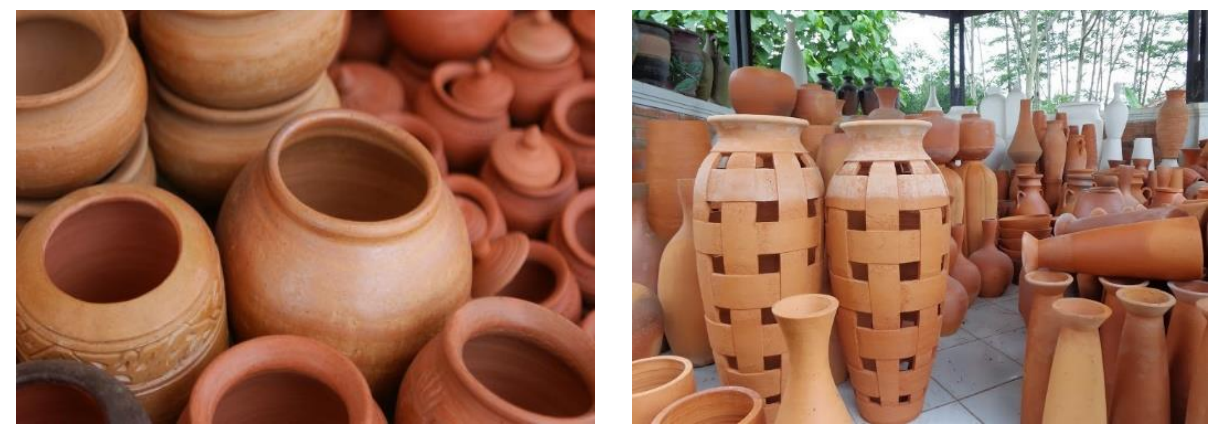

Figure 2: Ceramic clay types

Source: in the Keramik Plered webpage

The orders are mostly from the use of digital media channels which can lead to communication processes in marketing ceramic products, although not all Ceramic SMEs entrepreneurs utilize digital communication channels, because they tend to market personally and are direct in nature.

\section{Barriers to SME Digital Communication Channels}

The obstacles faced by ceramic SMEs entrepreneurs in general are a factor of tradition / culture that is strong and hereditary as a heritage because this ceramic production business is their main livelihood, but many of them work in other fields and do not want to be involved in business development which is owned by his parents even though they realize that the development of communication technology is very important but at the same time becomes an obstacle in using it besides economic or financial factors due to borrowing money from the bank they feel difficulties. This is consistent with the results of research conducted by Caiyong Zhuang et al. (2017) proved difficult for SMEs to borrow money from banks because of the inability of banks to access reliable SME financial information. In addition, from the interview results obtained information that to create a Website must spend a lot of funds and do not understand how to use it because of the generally low educational factors and only a few Ceramic SMEs that have high education, but their experience and skills in processing, designing and produce ceramics with attractive designs, no doubt due to the fact that they can sell ceramics domestically or export abroad with good results. In other words able to compete with ceramic products produced by other countries, such as China. To overcome this problem it is important for the role of government to help their difficulties given the digital platform launched by the government has been running.

\section{CONCLUSION}

Based on the results of research and discussion shows that ceramic SMEs entrepreneurs in the Center for Ceramic Industry, Plered Purwakarta Regency, West Java, Indonesia, many have not utilized digital channels to market ceramic products, many of the ceramic SMEs entrepreneurs use direct communication 
channels and direct communication. indirect nature and has a different effect in marketing ceramic products. In addition, the obstacle found in this study is a factor of tradition or culture that has been passed down as a heritage, then economic factors are the cause of the low use of digital channels. The findings in this study are interpersonal communication channels.

\section{BIODATA}

Poppy Ruliana, Dr., Dra., MSi, is a lecturer at LLDIKTI Region III DKI Jakarta, Indonesia who is employed at the InterStudi College of Communication, Jakarta, Indonesia

Irwansyah, Dr, MA, S, Sos is a lecturer of the Social Sciences Department of Communication, University of Indonesia, Jakarta, Indonesia

Susi Andrini, MSi, is a lecturer in the InterStudi College of Communication Studies, Jakarta, Indonesia

Kurnia, SE, MM is a lecturer in the InterStudi College of Communication Studies, Jakarta, Indonesia

\section{REFERENCES}

\section{Buku}

Prisgunanto, Ilham.2014. Komunikasi Pemasaran Era Digital. Jakarta: CV Prisani Cendekia

Ruliana, Poppy 2016. Komunikasi Organisasi, Teori dan Studi Kasus, Edisi Kedua.. Jakarta: RajaGrafindo Persada

Silalahi, Ulbert, 2009. Metode Penelitian Sosial. Bandung: PT Refika Aditama

\section{Journal}

Barbero, J.L., Casillas, J.C., Feldman, H.D. (2011), "Managerial capabilities and paths to growth as determinants of high-growth small and mediumsized enterprises", International Small Business Journal, Vol. 29 No.6, pp.671-694.

Barnes, D., Clear, F., Harindranath, G., Dyerson, R., Harris, L., Rea, A. (2012),

"Web 2.0 and micro-businesses: an exploratory investigation", Journal of Small Business and Enterprise Development, Vol. 19 No.4, pp.687-711.

Bordonaba-Juste, V., Lucia-Palacios, L., Polo-Redondo, Y. (2012), "The influence of organizational factors on e-business use: analysis of firm size", Marketing Intelligence \& Planning, Vol. 30 No.2, pp.212-229.

Bruhn, M., Schoenmueller, V., Schäfer, D.B. (2012), “Are social media replacing traditional media in terms of brand equity creation?" Management Research Review, Vol. 35 No.9, pp.770-790. 
Carroll, W.R., Wagar, T.H. (2010), "Is there a relationship between information technology adoption and human resource management?", Journal of Small Business and Enterprise Development, Vol. 17 No.2, pp.218-229.

Chao, C-A., Chandra, A. (2012), "Impact of owner's knowledge of information technology (IT) on strategic alignment and IT adoption in US small firms", Journal of Small Business and Enterprise Development, Vol. 19 No.1, pp.114-31.

Chatzoglou, P.D., Vraimaki, E., Diamantidis, A., Sarigiannidis, L. (2010), "Computer acceptance in Greek SMEs", Journal of Small Business and Enterprise Development, Vol. 17 No.1, pp.78-101.

Cho, S., Huh, J. (2010), “Content analysis of corporate blogs as a relationship management tool”, Corporate Communications: An International Journal, Vol. 15 No. 1, pp.30-48.

Ericsson Consumer Lab (2012), "10 hot consumer trends 2013", Ericsson Consumer Lab Report, Stockholm, Sweden.

Federico, J., Rabetino, R., Kantis, H. (2012), "Comparing young SMEs' growth determinants across regions", Journal of Small Business and Enterprise Development, Vol. 19 No.4, pp.575-588.

Fournier, S., Avery, J. (2011), “The Uninvited Brand”, Business Horizons, Vol. 54 No.3, pp.193-207.

Gabrielli, V., Balboni, B. (2010), “SME Practice Towards Integrated Marketing Communications”, Marketing Intelligence \& Planning, Vol. 28 No.3, pp.275-290.

Järvinen, J., Töllinen, A., Karjaluoto, H., Jayawardhena, C. (2012), ”Digital And Social Media Marketing Usage In B2B Industrial Sector", Marketing Management Journal, Vol. 22 No.2, pp.102-117.

Kaplan, A.M., Haenlein, M. (2010), "Users of the world, unite! The challenges and opportunities of Social Media", Business Horizons, Vol. 53 No.1, pp. 59-68.

Liu, Q., Karahanna, E., Watson, R.T. (2011), ’Unveiling User-Generated Content: Designing Websites To Best Present Customer Reviews", Business Horizons, Vol. 54 No.3, pp.231-240.

Malhotra, A., Kubowicz Malhotra, C., See, A. (2013), "How to create brand engagement on Facebook", MIT Sloan Management review, Vol. 54 No.2, pp.18-20.

Meske Christian and Stefan Stieglitz, 2017. Adoption and Use of Social Media in Small and Medium-Sized Enterprises,

Michaelidou, N., Siamagka, N.T., Christodoulides, G. (2011), “Usage, barriers and 
measurement of social media marketing: An exploratory investigation of small and medium B2B brands", Industrial Marketing Management, Vol. 40 No. 7, pp.1153-159.

Nuseir T, Mohammed, Al Ain, 2018). Digital Media Impact On Smes Performance In The Uae, Academy of Entrepreneurship Journal, Volume 24, Issue 2, 2018

O’Donnell, A. (2011), "Small Firm Marketing: Synthesising And Supporting Received Wisdom", Journal of Small Business and Enterprise Development, Vol. 18 No.4, pp.781-805.

Parrott, G., Roomi, M.A., Holliman, D. (2010), “An analysis of marketing programmes adopted by regional small and medium-sized enterprises", Journal of Small Business and Enterprise Development, Vol. 17 No.2, pp.184-203.

Parry, S., Jones, R., Rowley, J., Kupiec-Teahan, B. (2012), 'Marketing for survival: a comparative case study of SME software firms", Journal of Global Information Management, Vol 19 No.4, pp.712-728.

Rishika, R., Kumar, A., Janakiraman R., Bezawada, R. (2013), "The Effect Of Customers' Social Media Participation On Customer Visit Frequency And Profitability: An Empirical Investigation", Information Systems Research, Vol. 24 No. 1, pp.108-127.

Roosdhani Mohamad Rifqy, Purwo Adi Wibowo, Anna Widiastuti. 2012. Analysis of the Level of Use of Information and Communication Technology in Small and Medium Enterprises in the District. Jepara Journal of Economic and Business Dynamics, Vol 9, No. 2

Rowley, J. (2008), “Understanding digital content marketing”, Journal of Marketing Management, Vol. 24 No.5/6, pp.517-540.

Ruliana Poppy, Irwansyah, Suhendra Atmaja, Soebiagdo, Riyanto, 2018. Utilization of Social Media Among Small and Medium Enterprises (SMEs) Ceramics Center for Plered Ceramics Industry Centers in Purwakarta Regency. Journal of Communication, Inter-Communication, Vol 3, No 1 (2018) Vol 3, No

Taiminen. Heini dan Heikki Karjaluoto, 2015. The Usage Of Digital Marketing Channels In Smes. November 2015 Journal of Small Business and Enterprise Development 22(4):633-651 DOI: 10.1108/JSBED-05-20130073

Todorova G.2015. Marketing Communication Mix. Trakia Journal of Sciences, Vol. 13, Suppl.1, pp368-374

\section{Proceedings}

Caiyong Zhuang, Shanwei Lin, Fu Lin, 2017. The Analysis Of Digital Marketing Among Smes In Chaozhou City, Advances in Economics, Business and Management Research

(AEBMR), volume 37 International 
Conference on Transformations and Innovations in Management (ICTIM17), Atlantis Press,

\section{Internet}

artikel 6 (http://www.djmbp.esdm.go.id/sijh/UU_2008_20_About_Usaha_Mikro _Kecil_Dan_Menengah.pdf) artikel (http://www.djmbp.esdm.go.id/sijh/UU_2008_20_

https://goukm.id/apa-itu-ukm-umkm-startup/

Adapting EU regulation to the needs of micro-enterprises", European Commission, 2011 Report from the commission to the council and the European parliament. available at: http://eur-

lex.europa.eu/LexUriServ/LexUriServ.do?uri=COM:2011:0803:FIN:EN:P DF (accessed 20 December 2013).

Moyle, C.S. (2012), "How much time, money do small businesses spend on social media? [Infographic]", Vertical Response, October $30^{\text {th }}$, available at: http://www.verticalresponse.com/blog/how-much-time-and-money-dosmall-businesses-spend-on-social-media-infographic/ (accessed 20 December 2013).

Sayre, K., Rastogi, V., Zwillenberg, P., Visser, J., Sheerin, A. (2012), "Marketing capabilities for the digital age", Boston Consulting Group, available at: http://jcirera.files.wordpress.com/2012/02/bcg.pdf (accessed 2 February 2013)

Nielsen (2012), "The Nielsen global survey of social media usage", available at: http://www.nielsen.com/us/en/reports/2012/state-of-the-media-the-socialmedia-report-2012.html (accessed 2 April 2013).

https://www.google.com/search?safe=strict\&rlz=1C1GGRV_enID785ID785\&tb $\underline{m=i s c h \& s x s r f=A C Y B G N S 5 H b O p i n c 97 g e u u K z T c u r m N Y V v c A: 15769888 ~}$ $\underline{40703 \& q=\text { keramik+plered\&chips=q:keramik+plered,online_chips:kecama }}$ tan+plered+purwakarta\&usg=AI4_-kTiktrOTtqVaiNUceLd2a9-

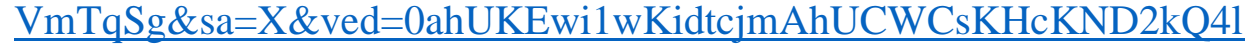
YILSgC\&biw=1292\&bih=594\&dpr=1\#imgrc=Y9Z8u72k2yV47M:

https://www.pahlevi.net/pengertian-usaha-kecil-menengah/ 